\title{
Analisis Kesulitan Pembelajaran Daring pada Mata Pelajaran Matematika di Tengah Pandemi Covid-19
}

\author{
Riskawati $^{*}$, Novianita Achmad ${ }^{2}$, Nursiya Bito ${ }^{3}$ \\ 1,2,3 Jurusan Matematika, Fakultas MIPA, Universitas Negeri Gorontalo, \\ Jl. Prof. Dr. Ing. B. J. Habibie, Tilongkabila, Kabupaten Bone Bolango, Gorontalo 96119, Indonesia
}

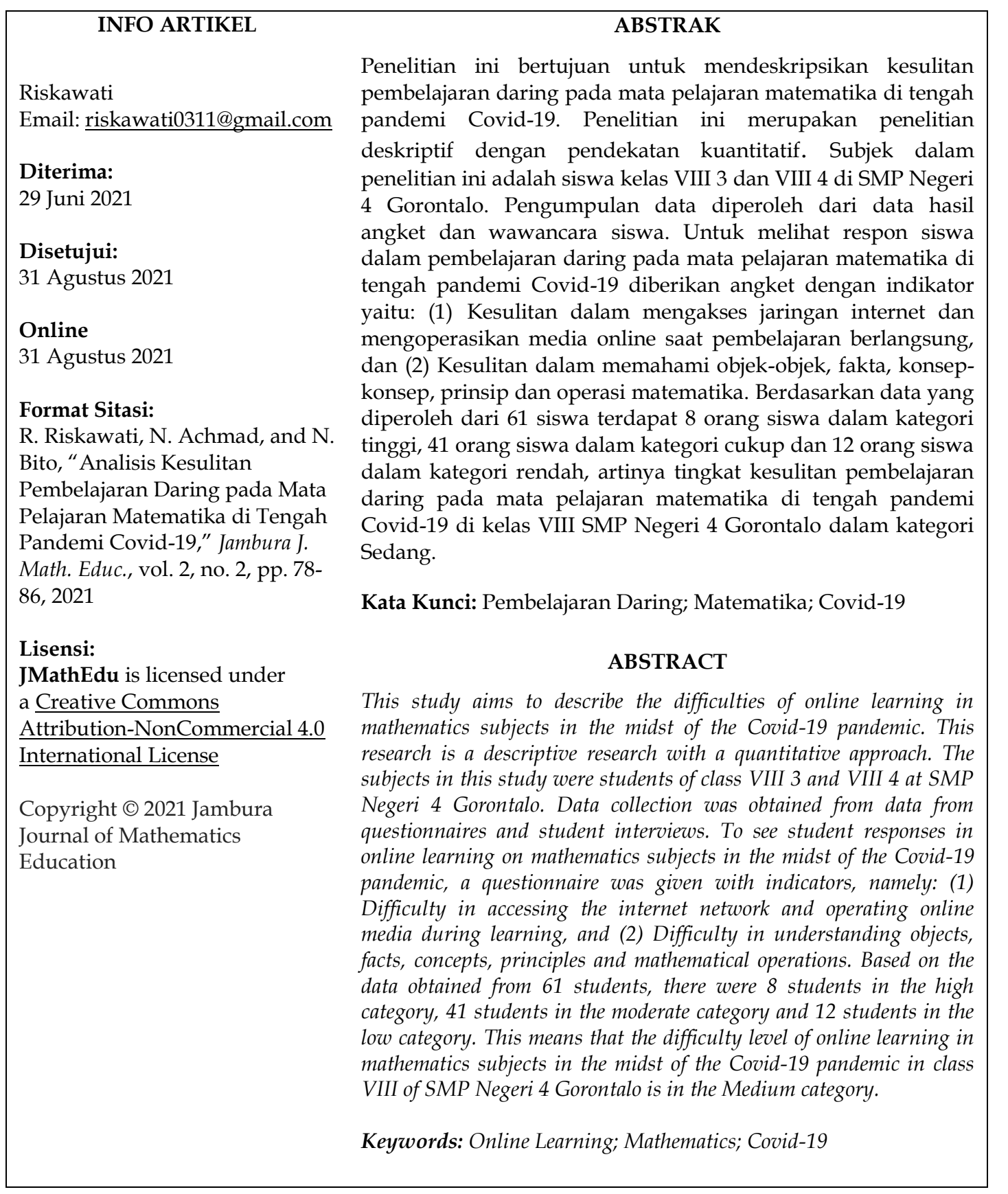


Riskawati, dkk | Analisis Kesulitan Pembelajaran Daring Pada Mata Pelajaran ...

\section{Pendahuluan}

Awal tahun 2020 dunia digemparkan dengan menyebar luas jenis virus baru yaitu coronavirus (sars-cov2) yang berasal dari China. Virus ini masuk ke Indonesia pada bulan maret 2020 [1]. penyebaran penyakit tersebut sangat cepat, bahkan di seluruh penjuru dunia saat ini sedang mengalami krisis kesehatan. Awalnya penyebaran covid 19 sangat berdampak pada kegiatan ekonomi yang mulai lesu. Akan tetapi, tidak hanya itu dilansir dari berita harian Kompas (2020) pemerintah di beberapa daerah juga membuat kebijakan penutupan jalan hingga pembatasan wilayah untuk warga yang ingin keluar masuk dalam suatu daerah yang juga disebut lockdown [2]. Dampak dari wabah tersebut juga dirasakan oleh dunia pendidikan yang mengharuskan pemerintah menerapkan beberapa peraturan yang mengharuskan untuk pelaksanaan pembelajaran disekolah secara daring (online). Pendidikan menuju pembelajaran daring (online) merupakan suatu keharusan agar standar mutu Pendidikan menjadi lebih baik apalagi di tengah pandemi Covid-19. Pembelajaran daring (online) adalah suatu sistem pembelajaran terbuka dan tersebar dengan menggunakan perangkat pedagogik, yang dimungkinkan melalui internet untuk memfasilitasi pembentukan proses pembelajaran dan pengetahuan melalui aksi dan intraksi yang berarti [3].

Perubahan penggunaan model pembelajaran yang terlalu tiba-tiba ini bisa berdampak pada proses belajar yang di alami siswa terutama pada mata pelajaran matematika. Tidak sedikit yang menganggap bahwa matematika adalah sebuah momok yang harus dihindari. Sebagaimana dalam [4] matematika dianggap sebagai pembelajaran yang sulit karena karakteristik metamatika bersifat abstrak, logis sistematis dan penuh dengan lambang serta rumus yang membingungkan. Kesulitan yang ada dalam pembelajaran matematika menuntut kreatifitas guru mata pelajaran untuk mengembangkan pelajaran baik dalam hal metode maupun media yang digunakan. Kesulitan belajar merupakan suatu hal yang menyebabkan terhambatnya proses pembelajaran sehingga proses pembelajaran tidak berjalan dengan baik. Kesulitan belajar adalah suatu kondisi dalam pembelajaran yang ditandai oleh hambatanhambatan tertentu untuk mencapai hasil belajar [5]. Kesulitan belajar siswa akan berdampak terhadap prestasi belajar siswa karena untuk memperoleh prestasi yang baik dapat diperoleh dari perlakuan belajar di sekolah maupun diluar sekolah dan atas ketentuan serta usaha siswa dalam belajar [6].

Dengan adanya pembelajaran daring dapat dilakukan dimana saja dan kapanpun tanpa harus bertatap muka. pembelajaran online atau e-learning adalah salah satu bentuk model pembelajaran yang difasilitasi dan didukung pemanfaatan teknologi informasi dan komunikasi [7] interaksi yang terjadi antara siswa dan siswa serta siswa dan guru hanya melalui media online seperti handphone, laptop, dan computer [8].Pada situasi ini guru di tuntut untuk dapat memanfaatkan kondisi yang ada sebaik mungkin. Guru harus selalu aktif dalam memberikan materi dan memberi informasi terkait dengan pembelajaran online saat ini serta memastikan semangat siswa tidak berkurang dalam mengikuti proses pembelajaran berlangsung melalui media online [9]. Tidak dapat dipungkiri dengan adanya suasana pembelajaran baru tentunya tidak begitu saja dapat beradaptasi dengan baik. Banyak sekali kendala-kendala yang dihadapi oleh pendidik dan siswa dalam proses pembelajaran jarak jauh. Kendala paling umum yaitu terbatasnya kuota internet, kesulitan dalam pemahaman materi matematika karena mengingat matematika juga merupakan mata pelajaran yang 
dianggap sulit oleh siswa. selain itu, bahkan beberapa siswa ada yang tidak memiliki smartphone, sehingga menghambat pelaksanaan proses pembelajaran secara daring.

Beberapa penelitian beberapa bulan terakhir proses pembelajaran selama pandemi Covid-19, seperti penelitian Andriani [10] dan Mustakim [11] yang melihat evaluasi pembelajaran online matematika di tingkat Sekolah Dasar. Kajian pembbelajaran online pada topik khusus di mmatematika juga banyak dilakukan selama pandemi Covid-19, seperti pembelajaran online pada topik bangun ruang sisi datar [12], matriks [13], dan persamaan kuadrat [14]. Selain itu, kajian pembelajaran matematika dengan memanfaatkan media E-Learning juga pada [15][16].

Banyaknya kajian terkait pembelajaran matematika secara daring menunjukkan bahwa topik ini masih sangat terbuka untuk dilakukan kajian lebih lanjut, terutama pada tingkat satuan pendidikan yang berbeda. Hal ini penting dilakukan karena karakteristik siswa atau peserta didik dalam setiap satuan pendidikan berbeda, sehingga respon dalam setiap pembelajaran yang diberikan juga akan berbeda. Pada penelitian ini, dilakukan kajian terkait kesulitan pembelajaran daring pada mata pelajaran matematika di tengah pandemi Covid-19.

\section{Metode}

Penelitian ini dilaksanakan di SMP Negeri 4 Gorontalo. Penelitian dilaksanakan pada tahun ajaran 2020/2021 disemester ganjil. Metode yang digunakan dalam penelitian ini adalah penelitian deskriptif dengan pendekatan kuantitatif, yaitu penelitian yang dimaksud untuk menyelidiki keadaan, kondisi atau hal lain-lain yang sdah disebutkan, yang hasilnya dipaparkan dalam bentuk laporan penelitian [17]. Penelitian deskriptif adalah penelitian yang bertujuan untuk mengambarkan fenomena, keadaan, variabel, gejala atau situasi pada saat sekarang [18]. Sumber data dalam penelitian ini adalah siswa kelas VIII SMP Negeri 4 Gorontalo yang berjumlah 66 siswa.

Variabel merupakan gejala yang bervariasi, yang menjadi objek penelitian. Variabel penelitan adalah objek penelitian atau apa yang menjadi titik perhatian suatu penelitian. Berdasarkan rumusan permasalahan atau definisi, maka dalam penelitian ini hanya ada satu variabel yaitu menyangkut Kesulitan pembelajaran daring pada mata pelajaran matematika di tengah pandemi Covid-19.

Dalam penelitian ini instrumen atau atau alat bantu yang digunakan adalah instrumen berupa angket dan pedoman wawancara. Instrumen angket itu sendiri terdiri dari 2 indikator; (1) Kesulitan dalam mengakses jaringan internet dan mengoperasikan media online saat pembelajaran berlangsung, dan 2) Kesulitan dalam memahami objek-objek, fakta, konsep-konsep, prinsip dan operasi matematika.

Prosedur pengumpulan data dalam penelitian ini dilakukan melalui dua tahap. Tahap pertama yaitu tahap pemberian angket. Angket merupakan teknik pengumpulan data yang efisien bila peneliti tahu dengan pasti variable yang akan diukur dan tahu apa yang bisa diharapkan responden [19]. Untuk melihat bagaimana kesulitan pembelajaran daring pada mata pelajaran matematika di tengah pandemic covid-19 maka diberikan angket yang telah disusun berdasarkan indikator yang telah ditentukan. Angket yang di berikan kepada siswa berjumlah 25 item pernyataan.

Pemberian angket ini dilakukan dengan cara online yang dibantu dengan google from. 
Tahap kedua yaitu wawancara, dimana Pernyataan-pernyataan yang telah diajukan melalui angket akan di sesuaikan dengan wawancara yang akan diajukan kembali kepada beberapa siswa dan guru matematika yang ada di lingkungan sekolah tersebut untuk mendukung penyataan-pernyataan sebelumnya yang mencakup semua indikator.

Data yang dianalisis berupa angket (kuesioner) respon siswa, namun sebelum data diolah kedalam bentuk presentase, angket (kuesioner) diberi skor dengan menggunakan skala Likert pada Tabel 1.

Tabel 1. Skor angket (kuesioner)

\begin{tabular}{ccc}
\hline \multirow{2}{*}{ Kategori Jawaban Peserta Didik } & \multicolumn{2}{c}{ Skor untuk butir pertanyaan } \\
\cline { 2 - 3 } & Positif & Negatif \\
\hline SS & 5 & 1 \\
S & 4 & 2 \\
RG & 3 & 3 \\
TS & 2 & 4 \\
STS & 1 & 5 \\
\hline
\end{tabular}

Keterangan:

$\begin{array}{llll}\text { SS } & =\text { Sangat Setuju } & \text { TS } & =\text { Tidak Setuju } \\ \text { S } & =\text { Setuju } & \text { STS } & =\text { Sangat Tidak Setuju } \\ \text { RG } & =\text { Ragu-Ragu } & & \end{array}$

Data kemudian diolah dalam bentuk presentase sebagai berikut:

$$
\% \text { Respon Peserta Didik (RPD) }=\frac{\sum_{i=1}^{n} R P D}{R P D \text { Maksimum }} \times 100 \%
$$

Keterangan:

$$
\begin{array}{ll}
\% \mathrm{RPD} & =\text { Persentase Respon Perseta Didik (RPD) } \\
\sum_{i=1}^{n} R P D & =\text { Total Skor Respon Pesera Didik (RPD) tiap item pertanyaan } \\
\text { RPD Masimum } & =n \times \text { skor pilihan terbaik } \\
& =n \times 4 \text { dengan } n \text { adalah banyaknya seluruh responden }
\end{array}
$$

Menginterpretasikan presentase respon peserta didik, dapat dikelompokkan berdasarkan klasifikasi [9] yang disajikan pada Tabel 2 .

Tabel 2. Klasifikasi Respon Peserta Didik

\begin{tabular}{cc}
\hline Interval & Kategori \\
\hline$x \geq(\bar{x}+S D)$ & Tinggi \\
$(\bar{x}-S D)<x<(\bar{x}+S D)$ & Sedang \\
$x \leq(\bar{x}-S D)$ & Rendah \\
\hline
\end{tabular}

\section{Hasil dan Pembahasan}

\subsection{Hasil}

Penelitian ini bertujuan untuk mengetahui kesulitan siswa dalam pembelajaran daring pada mata pelajaran matematika di tengah pandemi Covid-19. Adapun data angket diperoleh dari dua kelas yaitu kelas VIII 2 sebanyak 33 pserta didik, dan VIII 3 sebanyak 33 siswa. Sehingga total siswa yang mengisi angket berjumlah 66 siswa. 
Namun siswa yang mengisi angket hanya berjumlah 61 orang, 5 siswa lainnya tidak mengisi angket atau dinyatakan tidak hadir.

Pada penelitian ini data yang diperoleh untuk melihat tingkat kesulitan pembelajaran daring pada mata pelajaran matematika di tengah pandemi Covid-19. Analisis Kesulitan pembelajaran daring pada siswa ini terdiri atas dua indikator yaitu: 1) Kesulitan dalam mengakses jaringan internet dan mengoperasikan media online saat pembelajaran berlangsung, dan 2) Kesulitan dalam memahami objek-objek, fakta, konsep-konsep, prinsip dan operasi matematika.

Berikut peneliti akan mendeskripsikan kesulitan pembelajaran daring pada mata pelajaran matematika di tengah masa pandemi Covid-19. Nilai angket kesulitan pembelajaran disajikan pada Tabel 3 .

Tabel 3. Hasil Nilai Angket Kesulitan Pembelajaran Online dalam pembelajaran Matematika

\begin{tabular}{|c|c|c|c|c|c|}
\hline No. Responden & Nilai & Kategori & No. Responden & Nilai & Kategori \\
\hline 1 & 55 & Sedang & 32 & 42 & Rendah \\
\hline 2 & 62 & Sedang & 33 & 50 & Sedang \\
\hline 3 & 52 & Sedang & 34 & 46 & Rendah \\
\hline 4 & 62 & Sedang & 35 & 61 & Sedang \\
\hline 5 & 46 & Rendah & 36 & 65 & Tinggi \\
\hline 6 & 54 & Sedang & 37 & 68 & Tinggi \\
\hline 7 & 54 & Sedang & 38 & 37 & Rendah \\
\hline 8 & 46 & Rendah & 39 & 60 & Sedang \\
\hline 9 & 60 & Sedang & 40 & 54 & Sedang \\
\hline 10 & 48 & Sedang & 41 & 57 & Sedang \\
\hline 11 & 53 & Sedang & 42 & 57 & Sedang \\
\hline 12 & 51 & Sedang & 43 & 60 & Sedang \\
\hline 13 & 52 & Sedang & 44 & 56 & Sedang \\
\hline 14 & 76 & Tinggi & 45 & 45 & Rendah \\
\hline 15 & 69 & Tinggi & 46 & 54 & Sedang \\
\hline 16 & 58 & Sedang & 47 & 46 & Rendah \\
\hline 17 & 59 & Sedang & 48 & 54 & Sedang \\
\hline 18 & 67 & Tinggi & 49 & 64 & Sedang \\
\hline 19 & 61 & Sedang & 50 & 48 & Sedang \\
\hline 20 & 46 & Rendah & 51 & 50 & Sedang \\
\hline 21 & 81 & Tinggi & 52 & 54 & Sedang \\
\hline 22 & 54 & Sedang & 53 & 50 & Sedang \\
\hline 23 & 49 & Sedang & 54 & 42 & Rendah \\
\hline 24 & 39 & Rendah & 55 & 53 & Sedang \\
\hline 25 & 56 & Sedang & 56 & 64 & Sedang \\
\hline 26 & 68 & Tinggi & 57 & 52 & Sedang \\
\hline 27 & 58 & Sedang & 58 & 56 & Sedang \\
\hline 28 & 55 & Sedang & 59 & 44 & Rendah \\
\hline 29 & 53 & Sedang & 60 & 70 & Tinggi \\
\hline 30 & 34 & Rendah & 61 & 63 & Sedang \\
\hline 31 & 48 & Sedang & & & \\
\hline
\end{tabular}


Berdasarkan Tabel 3. dapat dilihat bahwa dari 61 siswa terdapat 8 orang siswa dalam kategori tinggi, 41 orang siswa dalam kategori cukup dan 12 orang siswa dalam kategori rendah. Sehingga dapat diketahui bahwa tingkat kesulitan pembelajaran daring pada mata pelajaran matematika siswa kelas VIII SMP Negeri 4 Gorontalo cenderung Sedang.

Adapun data hasil penelitian untuk tiap indikator dapat dilihat pada sajian data berikut.

\subsubsection{Kesulitan dalam mengakses jaringan internet dan mengoperasikan media online saat pembelajaran berlangsung}

Klasifikasi kesulitan pembelajaran daring pada indikator 1, yaitu kesulitan mengakses jaringan internet dan mengoperasikan media online saat pembelajaran berlangsung disajikan pada Tabel 4 .

Tabel 4. Klasifikasi kesulitan pembelajaran daring pada indikator 1

\begin{tabular}{ccc}
\hline Interval & Kategori & Frekuensi \\
\hline$x \geq(10)$ & Tinggi & 14 \\
$(6)<x<(10)$ & Sedang & 42 \\
$x \leq(6)$ & Rendah & 5 \\
\hline
\end{tabular}

Berdasarkan Tabel 4 dapat diketahui bahwa sampel penelitian yang memiliki skor angket lebih besar sama dengan 10 sebanyak empat belas orang tingkat kesulitan siswa dalam mengakses jaringan internet dan mengoperasikan media online saat pembelajaran berlangsung pada kategori tinggi. Sampel yang memiliki skor 6 sampai kurang dari 10 berjumlah 42 orang berada pada ketegori sedang, sedangkan sampel yang memiliki skor kurang dari sama dengan 6 dengan jumlah lima orang tergolong kategori rendah. Maka dapat disimpulkan bahwa dari 61 siswa yang ada pada indikator 1 yaitu siswa yang memiliki kesulitan dalam mengakses jaringan internet dan mengoperasikan media online saat pembelajaran berlangsung tergolong dalam kategori Sedang.

\subsubsection{Kesulitan dalam memahami objek-objek, fakta, konsep-konsep, prinsip dan operasi matematika}

Klasifikasi kesulitan pembelajaran daring pada indikator 1, yaitu kesulitan memahami objek-objek, fakta, konsep-konsep, prinsip dan operasi matematika disajikan pada Tabel 5.

Tabel 5. Klasifikasi kesulitan pembelajaran daring pada indikator 2

\begin{tabular}{ccc}
\hline Interval & Kategori & Frekuensi \\
\hline $\mathrm{x} \geq(54)$ & Tinggi & 11 \\
$(38)<x<(54)$ & Sedang & 38 \\
$\mathrm{x} \leq(38)$ & Rendah & 12 \\
\hline
\end{tabular}


Berdasarkan Tabel 5, dapat diketahui bahwa sampel penelitian yang memiliki skor angket lebih besar sama dengan 54 sebanyak sebelas orang tingkat kesulitan siswa dalam memahami objek-objek, fakta, konsep-konsep, prinsip dan operasi matematika pada kategori tinggi. Sampel yang memiliki skor 38 sampai kurang dari 54 berjumlah tiga puluh delapan orang berada pada ketegori sedang, sedangkan sampel yang memiliki skor kurang dari sama dengan 38 dengan jumlah dua belas orang tergolong kategori rendah. Maka dapat disimpulkan bahwa dari 61 siswa yang ada pada indikator 2 yaitu siswa yang memiliki kesulitan dalam memahami objek-objek, fakta, konsep-konsep, prinsip dan operasi matematika tergolong dalam kategori sedang.

\subsection{Pembahasan}

Diketahui bahwa gambaran dari kesulitan pembelajaran daring pada mata pelajaran matematika di tengah masa pandemi Covid-19 secara umum berdasarkan dua indikator yang telah di buat. Hasil data yang diperoleh dari 61 siswa, terdapat 8 orang siswa berada pada kategori tinggi, 41 orang siswa berada pada kategori sedang, dan 12 orang siswa berada pada kategori rendah. Artinya tingkat kesulitan pembelajaran daring pada mata pelajaran matematika cenderung sedang yang dapat dilihat dari beberapa indikator yaitu:

\subsubsection{Kesulitan dalam mengakses jaringan internet dan mengoperasikan media online saat pembelajaran berlangsung}

Diketahui bahwa sampel penelitian yang memiliki skor angket lebih besar sama dengan 10 sebanyak empat belas orang tingkat kesulitan siswa dalam mengakses jaringan internet dan mengoperasikan media online saat pembelajaran berlangsung pada kategori tinggi. Sampel yang memiliki skor 6 sampai kurang dari 10 berjumlah 42 orang berada pada ketegori sedang, sedangkan sampel yang memiliki skor kurang dari sama dengan 6 dengan jumlah lima orang tergolong kategori rendah.Maka dapat disimpulkan bahwa dari 61 siswa yang ada pada indikator 1 yaitu siswa yang memiliki kesulitan dalam mengakses jaringan internet dan mengoperasikan media online saat pembelajaran berlangsung cenderung sedang.

\subsubsection{Kesulitan dalam memahami objek-objek, fakta, konsep-konsep, prinsip dan operasi matematika}

Pada indikator ini diketahui bahwa sampel penelitian yang memiliki skor angket lebih besar sama dengan 54 sebanyak sebelas orang tingkat kesulitan siswa dalam memahami objek-objek, fakta, konsep-konsep, prinsip dan operasi matematika pada kategori tinggi. Sampel yang memiliki skor 38 sampai kurang dari 54 berjumlah tiga puluh delapan orang berada pada ketegori sedang, sedangkan sampel yang memiliki skor kurang dari sama dengan 38 dengan jumlah dua belas orang tergolong kategori rendah, maka dapat disimpulkan bahwa dari 61 siswa yang ada pada indikator 2 yaitu siswa yang memiliki kesulitan dalam memahami objek-objek, fakta, konsep-konsep, prinsip dan operasi matematika cenderung sedang.

\section{Kesimpulan}

Pada pembelajaran daring di tengah pandemi Covid-19 saat ini beberapa siswa masih mengalami kesulitan dalam pembelajaran terutama pada mata pelajaran matematika. Hasil analisis menunjukkan bahwa tingkat kesulitan siswa SMP Negeri 4 Gorontalo 
dalam mengikuti pembelajaran daring pada mata pelajaran matematika berada pada kategori sedang. Hal ini ditunjukkan dengan mayoritas siswa mengalami kesulitan dengan kategori sedang, dan hanya sebagian kecil yang mengalami kesulitan dalam kategori tinggi ataupun rendah.

\section{Referensi}

[1] Y. Yuliyana, "Corona Virus Disease (covid-19): Sebuah Tinjauan Literatur," Jurnal Welleness and Healthy Magazine, vol. 2, no. 1, pp. 187-192, 2020.

[2] O. I. Handarini, and S. S. Wulandari, "Pembelajaran Daring Sebagai Upaya Study From Home (SFH) Selama Pandemi Covid 19", Jurnal Pendidikan Administrasi Perkantoran (JPAP), Vol. 8, no. 3, pp. 496-503, 2020.

[3] N. D. Dabbagh, Online Learning, Concepts, Strategies and Application. Ohio: Person, 2005.

[4] R. N. Auliya, "Kecemasan matematika dan pemahaman matematis," Formatif: Jurnal Ilmiah Pendidikan MIPA., vol. 6, no. 1, pp. 12-22, 2016.

[5] H. Cahyono, "Faktor-faktor Kesulitan Belajar Siswa MIN JANTI," Jurnal Dimensi Pendidikan dan Pembelajaran, Vol. 7, no. 1, pp. 1-4, 2019.

[6] F. Jamal, "Analisis Kesulitan Belajar Siswa Dalam Mata Pelajaran Matematika Pada Materi Peluang Kelas XI IPA SMA Muhammadiyah Meulaboh Johan Pahlawan," Jurnal MAJU (Jurnal Pendidikan Matematika), Vol. 1, No. 1, pp. 18-36, 2014.

[7] R. A. Apsari, S. Sripatmi, M. A. Maulyda, and N. H. Salsabila, "Pembelajaran Matematika dengan Media Obrolan Kelompok Multi-Arah sebagai Alternatif Kelas Jarak Jauh," Jurnal Elemen, vol. 6, no. 2, pp. 318-332, 2020.

[8] H. H. Batubara, Media Pembelajaran Efektif, Semarang: Fatwa Publishing, 2020.

[9] N. A. Yensy, "Efektifitas Pembelajaran Statistika Matematika Melalui Media Whatsapp Group Ditinjau dari Hasil Belajar Mahasiswa (Masa Pandemik Covid 19)," Jurnal Pendidikan Matematika Raflesia., vol. 6, no. 2, pp. 65-74, 2020.

[10] R. Andriani, "Evaluasi Pembelajaran Onlne Matematika Siswa kelas 5 SD Negeri 5 Metro Pusat," Institut Agama Islam Negeri (IAIN), Metro Lampung, 2020.

[11] M. Mustakim, "Efektivitas Pembelajaran Daring Menggunakan Media Online Selama Pandemi Covid- 19 Pada Mata Pelajaran Matematika", Al Asma: Journal of Islamic Education, Vol. 2, no. 1, pp. 1-12, 2020.

[12] A. W. Abdullah, N. Achmad, and N. C. Fahrudin, “Deskripsi Hasil Belajar Matematika Siswa Melalui Pembelajaran Daring pada Pokok Bahasan Bangun Ruang Sisi Datar," Euler J. Ilm. Mat. Sains dan Teknol., vol. 8, no. 2, pp. 36-41, Dec. 2020, doi: 10.34312/ euler.v8i2.10324.

[13] A. W. Abdullah, D. R. Isa, and N. F. Podungge, "Analisis Hasil Balajar Matematika Siswa pada Meteri Matriks Melalui Pembelajaran Berbasis E-Learning," Euler J. Ilm. Mat. Sains dan Teknol., vol. 9, no. 1, pp. 1-5, Apr. 2021, doi: 10.34312/euler.v9i1.10325.

[14] S. Zakiyah, K. Usman, and A. P. Gobel, "Deskripsi Kemampuan Pemecahan Masalah Matematika Melalui Pembelajaran Daring pada Materi Persamaan 
Riskawati, dkk | Analisis Kesulitan Pembelajaran Daring Pada Mata Pelajaran ...

Kuadrat," Jambura J. Math. Educ., vol. 2, no. 1, Mar. 2021, doi: 10.34312/jmathedu.v2i1.10268.

[15] E. Hulukati, N. Achmad, and M. A. Bau, "Deskripsi Penggunaan Media ELearning dalam Pembelajaran Matematika di Masa Pandemi Covid-19," Jambura J. Math. Educ., vol. 2, no. 1, pp. 21-27, Mar. 2021, doi: 10.34312/jmathedu.v2i1.10061.

[16] E. Hulukati, N. Achmad, and M. A. Bau, "Deskripsi Penggunaan Media ELearning dalam Pembelajaran Matematika di Masa Pandemi Covid-19," Jambura J. Math. Educ., vol. 2, no. 1, pp. 21-27, Mar. 2021, doi: 10.34312/jmathedu.v2i1.10061.

[17] S. Arikunto, Prosedur Penelitian Suatu Pendeaktan Praktik. Jakarta: Rineka Cipta, 2014.

[18] Sugiyono, Metode Penelitian Kuantitatif, Kualitatif dan RED. Bandung: Alfabeta, 2013.

[19] M. F. Annur and H. Hermansyah, "Analisis Kesulitan Mahasiswa Pendidikan Matematika Dalam Pembelajaran Daring Pada Masa Pandemi Covid-19", Jurnal Kajian, Penelitian dan Pengembangan Kependidikan, Vol. 11, No. 2, pp. 195-201, 2020. 